\title{
Investigation of the functional brain-derived neurotrophic factor gene variant Val66MET in migraine
}

\author{
Martin Marziniak · Anna Laura Herzog • \\ Rainald Mössner · Claudia Sommer
}

Published online: 18 July 2009

(C) Springer-Verlag 2009

Erratum to: J Neural Transm (2008) 115:1321-1325

DOI 10.1007/s00702-008-0056-1

The correct author list is given here:

Martin Marziniak - Anna Laura Herzog - Rainald Mössner · Claudia Sommer

The online version of the original article can be found under doi:10.1007/s00702-008-0056-1.

M. Marziniak · C. Sommer

Department of Neurology, University of Würzburg,

Würzburg, Germany

M. Marziniak

Department of Neurology, Saarland University,

Homburg/Saar, Germany

M. Marziniak $(\square)$

Department of Neurology, University of Münster,

Albert-Schweitzer-Strasse 33, 48149 Münster, Germany

e-mail: marzinia@uni-muenster.de

\section{A. L. Herzog · R. Mössner}

Department of Psychiatry and Psychotherapy,

University of Würzburg, Würzburg, Germany

R. Mössner

Department of Psychiatry and Psychotherapy,

University of Bonn, Bonn, Germany 